\title{
Co-occurences of Kok and other Markers in Colloquial Jakartan Indonesian
}

\author{
Rika Mutiara \\ Esa Unggul University \\ rika.mutiara@esaunggul.ac.id \\ DOI: http://dx.doi.org/10.1836/jopr.v1i1.43-61
}

Submission
Track:
Received:
27-03-2019
Final Revision:
01-03-2019
Available online:
03-04-2019
Corresponding
Author:
rika.mutiara@esaunggul.ac.id

\begin{abstract}
This study analyzes discourse marker (DM) kok (why) in colloquial Jakartan Indonesian. Co-occurences of markers are noticeable features. It focuses on examining the emotive and textual functions of the cooccurences of kok and other markers. This study applied corpus methods. It was found that there are 7 markers co-occur with kok namely tho, eh, oh, lha, wah, ah, and ih that always appear on the left side of kok. Only DM sih occurs on the right side. In emotive functions, the co-occurrences were used to show shock, disappointment, and disgust. Three markers might occur together in one utterance which cause more complex senses. Some utterances with kok appear repeatedly in the form of questions. It seems that in questions with kok, the speakers feel more curious and demand more responses. In textual functions, the speakers use the co-occurrences to raise a topic, emphasize, demand answers, and negotiate. Moreover, it was also used when the speakers have just noticed something and tried to make the interlocutors notice.

Keywords: discourse marker, co-occurrence, emotive function, textual function
\end{abstract}

\section{INTRODUCTION}

Indonesian is a national language of Indonesia which is an archipelago that has many local languages. As a national language in such country, Indonesian has some local variations. One of the variations is colloquial Jakartan Indonesian. This variety is spoken in Jakarta, the capital city of Indonesia. As the capital city, people with different local languages come to Jakarta. The Jakartan Indonesian might be influenced by the local languages. The influences 
can be in the aspects related to discourse. In colloquial language, discourse marker (DM) is a feature that distinguishes colloquial language from formal spoken language and written language. Its meanings, moreover, might change from one situation to the other ones (Aijmer, 2014). Therefore, studying the utterances in dialogues to see the context is necessary.

DM is a part of pragmatic marker. DMs occur to create meaning as a whole by joining several elements in discourse. They are used by the participants in discourse to make the optimum sense of their utterances are delivered (Schiffrin, 2003). They, moreover, guide the listeners to make interpretation based on the message they heard (Han, 2011; Schiffrin, 2003).

Fraser (1996, p. 169) mentioned that DM is a type of pragmatic marker that "signals the relationship of the basic message to the foregoing discourse." According to Biber, Johansson, Conrad, \& Finegan (1999, p.1046) it is "loosely attached to the clause and connected with ongoing interaction." As it carries discourse functions, it represents how the speakers manage the discourse in conversation in order to deliver and understand meanings. It is also defined as "a syntactically heterogeneous class of expressions which are distinguished by their function in discourse and the kind of meaning they encode" (Blakemore, 2004, p.221). From all definitions, it can be seen that DMs contribute to meaning making.

Some studies focused on the functions of DMs. Wang (2011) studied DMs ano in Japanese and nage in mandarin Chinese. They function to develop close relationship among speakers. The DMs are used as a politeness strategy in which the speakers reduced the potency of his own or interlocutor's faces threatening acts. It is a part of speakers' ways to show emotions with considering the effects to the interlocutors. In addition, they were also used when the speakers found sameness with their interlocutors. Furthermore, they give color to the nature of conversation. Fischer in Schiffrin (1987) mentioned they influence turn taking system and the flow of information in conversation. DMs do not only affect the coherency of discourse but also influence the relationship among the speakers (Furman \& Özyürek, 2007). They might occur in transition. Besides, they appear to show how speakers and hearers involved in the message (Biber, et al., 1999).

As carrying emotive functions, DMs show stance (Aijmer, 2014; Han, 2011; Hiramoto, 2012). According to Biber \& Conrad (2003), stance carries feelings and assessment. Thus, the speakers try to make others understand what they feel and think about even though they do not directly use content words to express feelings. 
Textual functions mean how DMs are applied to organize texts such as in making the listeners pay attention to the messages that are going to deliver, marking structure of the texts, setting up boundary, and switching topics (Aijmer \& Rühlemann, 2015). DMs are used to make coherence in discourse (Schiffrin, 1992). They are applied to make the texts make sense and easily to be understood.

The study of DMs in Catalan and Spanish has similarity to the present study (Cuenca and Marin, 2009). It discussed the co-occurences of two markers. However, the term cooccurrence in this study is different from the one in the present study. It refers to two or more words occur as a chunk in Cuenca and Marin's study while, in the present study, it was used to define as a word(s) that occur together within the span of four words to the left and right. The previous study explored the functional category of discourse markers and distributional properties. It was found that two or more markers might co-occur.

Sneddon (2006) also studied DMs in colloquial Jakartan Indonesia. The DMs are deh, dong, kan, kek, kok, loh, mah, masa, nah, nih, tuh, sih, ya/yah, and yuk. The discussion of the co-occurences in Sneddon's work is limited. It only gives some examples of what DMs cooccur with other DMs. According to him, the function of co-occurences is to build connection among speakers in conversation. Most examples given in his work were not given in wider chunk of dialogue. Furthermore, the context of the utterances must be considered. It did not consider how the co-occurences carry functions particularly textual and emotive functions. Besides, the co-occurences that were investigated are only the DM and DM. Co-occurences to other markers such as interjections have not been studies. The present study gives contribution on the study of co-occurences of DM kok and other markers (DMs and interjections) especially in their textual and emotive functions.

One of the DMs in colloquial Jakartan Indonesia is kok. Kamus Besar Bahasa Indonesia (KBBI) which is an Indonesian-Indonesian dictionary published by the government gives two definitions for kok. The first one is as a word that functions to emphasize and strengthen speaker's intention. The second one, it is a synonym of mengapa and kenapa (why). As a synonym of mengapa and kenapa, when the speakers use kok, they ask for 
reasons from other participants in the dialogue. They expect explanation to answer their questions.

Schiffrin (2003) mentioned that DMs have cognitive, expressive, textual, and social functions in a discourse. From DMs, speakers' thought and emotion that are not delivered directly by using content words can be realized. Moreover, it gives views on how the speakers construct dialogue in such a way to deliver their ideas. The speakers also consider their relationship with the listeners and tried to manage it in social interaction. For the case of kok, it was found that kok tends to occur with other markers in utterances. As we have shown before, the position of the other markers can be on the left or right side of kok. In addition, their co-occurrences tend to be with other markers that carries exclamation in meaning such as wah (Anonymous, 2017). Words that carry exclamation are called as interjections such as oh, yeah, and wow. Interjection is a type of pragmatic marker (Aijmer, 2014). Like DM, its occurrences can be structurally independent. In addition, they carry speakers' emotions (Biber, et al., 1999; Fraser, 1996; Neal, 2014;). Neal (2014, p. 251) stated they "connect utterances to foregoing talk, they act as tags, they fill pause, they signal listener responses, and assessments, all in addition to expressing strong emotion." Oh shows speakers' participation in discourse. By producing oh they sign they receive information. Furthermore, oh that occurs in the question demands more detailed information from the ones that gave the information (Schiffrin, 1993). Thus, it plays roles in creating the texts and showing emotions. The findings are much related to the textual and emotive functions.

For the case emotive function, the nature of DMs and interjections enable them to do so. Besides, it seems that the construction of co-occurences of $k o k$ and other markers carries functions related to the way the speakers construct the dialogues. It is about the textual function of DMs. Intriguing by the findings, this study sought to answer the research questions as follows: 1). What are the emotive functions of the co-occurences of kok and other discourse markers? 2). What are the textual functions of the co-occurences of kok and other discourse markers?

\section{RESEARCH METHOD}

The present study applies corpus methods in discourse analysis. In doing so, quantitative considerations are counted. It produced results that give description and explain phenomena that is investigated in discourse (Partington in Thornbury, 2010). The use of 
corpus study to analyze DMs is recognized as an effective way because DMs are lexis that can be obtained easily by using the corpus tool. Lists of concordance lines of DMs can be provided. Furthermore, it can shed light on how speakers use DMs in order to optimize the sense of the message to be understood by the listeners (Rühlemnann, 2010). This study is limited only to emotive and textual functions and these functions are possible to be examined by a corpus method. As a study that applied corpus methods, first, the corpus was built by compiling the data from CHILDES (Child Language Data Exchange System). The size of the corpus is around 370,000 words. Next, the collocates of kok were investigated. Based on the wordlist of the collocates, the words that belong to DMs were selected. Close examination of the concordance lines was conducted to see the textual and emotive functions of the cooccurrences.

\section{RESULTS \& DISCUSSION}

It was found that markers on the left side of kok are lho, eh, oh, lha, wah, ah, and ih. On the right side, there is only sih. Only lho and sih that belong to the classification of DMs of colloquial Jakartan Indonesian by Sneddon (2006). Lha was not included in the classification. However, it is considered to be a DM in this study because its function and meaning almost similar to lho. The DMs, therefore, are lho, lha, and sih while the interjections are eh, oh, wah, ah, and ih. Their co-occurences with kok carry the sense of exclamation. The cooccurences occur in statements and questions. All of them function to show that the speakers feel shocked and surprised.

\section{Lho and Kok}

In this co-occurrence, kok appear in the questions. They can appear as chunks. Furthermore, they can be separated by some words such as in lho itu bekas jeruk kok and lho dia kok. Lho functions to show surprise (Sneddon, 2006). When tho and kok co-occur, it makes the speakers asked for reasons with surprise. In addition, the speaker used it when he negotiated his idea in order not do particular action.

$$
\begin{array}{cc}
\text { A: Burungnya kan } & \text { kesian ditembak } \\
\text { bird kan pitty shot }
\end{array}
$$




$\begin{array}{clllll}\begin{array}{c}\text { B: (B)urung } \\ \text { bird }\end{array} & \begin{array}{l}\text { apa? } \\ \text { what }\end{array} & & & \\ \text { A: Kalo yang } & \text { terbang, } & \text { jangan } & \text { ditembak, } & \text { kesian } & \\ \text { If } & \text { which fly } & \text { don't } & \text { shot } & \text { pitty } & \\ \text { B: (B)urung, } & \text { (b)ur(ung), } & \text { (ger)eja } & & & \\ \text { bird } & \text { bird } & \text { church } & & & \text { kesian } \\ \text { A: Burung, } & \text { burung } & \text { gereja } & \text { jangan } & \text { ditembak, } & \text { pitty } \\ \text { bird } & \text { bird } & \text { church } & \text { don't } & \text { shot } & \end{array}$

B: Tembak aja shoot just

A: lho, kok ditembak?

DM DM shot

B: Galak tapi

fierce but

A: It's pitty to shot the bird.

B: Which bird?

A: If the bird is flying, don't shoot, it's pitty.

B: Sparrow.

A: But fierce.

A: Don't shoot sparrows. It's pitty.

B: Just shoot.

A: How come it was shot?

B: It's fierce.

A felt shock because he requested B not to shot from the beginning. He produced two imperative utterances that requested B not to shot the bird. He also gave reason why he made such instruction. Nevertheless, B still kept his intention to shot. Through the question lho, kok, ditembak, A wonder why B persisted to do the action.

In another case, lho kok occurs as one phrase in one utterance. In the dialog below, the participants are a child and an adult. The adult is called as om (uncle).

$\begin{array}{clllll}\text { A: Om } & \text { Okki, } & \text { Om } & \text { Okki, ambil sendok } & \text { dong! } \\ \text { uncle } & \text { O } & \text { uncle } & \text { O take spoon } & \text { DM } \\ \text { B: Ya, } & \text { ambil } & \text { sendiri } & \text { dong, tuh. } & & \end{array}$


DM take alone DM DM

A: Aaah.

Exc

B: Lho kok?

DM DM

A: Uncle Okki, Uncle Okki, please take a spoon for me.

B: Please, do it by yourself.

A: Ah.

B: How come?

Through lho kok, B questioned A's response to his instruction. Like in the first dialogue given as the example, the speakers that produced lho kok made imperative utterance before he produced lho kok. In this dialogue, it can be seen when the speaker said ya, ambil sendiri, dong. The sense in the dialogue tends to be imperative.

Lho kok is not only a response to an utterance but it can be a response to an action that was seen by the speaker as in the following dialogue.

$\begin{array}{crlll}\text { A: Oke } & \text { deh, } & \text { maen cukur-cukuran } & \text { deh. } \\ \text { okay } & \text { DM } & \text { play shave } & \text { DM } \\ \text { B: Kompornya } & \text { beresin } & \text { ya? } \\ \text { stove } & & \text { tidy.up } & \text { DM } & \\ \text { C: Eh, } & \text { liat! } & & \\ \text { Exc } & \text { look } & & \\ \text { B: Lho, } & \text { kok } & \text { digunting? } & \\ \text { DM } & \text { DM } & \text { cut } & \end{array}$

A: Okay, let's play, pretend we do shaving.

B: Should we tidy up the stove?

A: Hey, look.

B: How come did you cut it?

Speaker $\mathrm{C}$ asked other participants in the conversation to look at him. After that, B questioned about it by saying lho, kok digunting? It is not only language produced but also 
the sudden actions done by the other participant that created situation in which B shows shock.

Feeling of shock in speaker's question can be accompanied by the feeling of disappointment as can be seen in the following dialogue.

$\begin{array}{ccll}\text { A: Lho, } & \text { kok } & \text { rumahnya } & \text { kosong? } \\ \text { DM } & \text { DM } & \text { house-nya } & \text { empty } \\ \text { B: Rumahnya mau } & \text { dimasuki } & \text { oleh binatang. } \\ \text { house } & \text { will enter } & \text { by animal } \\ \text { A: Yah, } & \text { kosong. } & & \\ \text { DM } & \text { empty } & & \end{array}$

A: How come was the house was empty?

B: The house will be entered by animals.

A: Oh no. Empty.

B gives a reason to A's question. After hearing it, A mentioned again the emptiness of the house with disappointing tone.

Lho kok might occur in sequences showing how intriguing the phenomenon for the speaker. A produced lho kok twice in one speaking turn. By doing this, A has questions in his mind. As a response, B does not give reason to answer A's question. He gives other information that might be helpful to answer A's questions.

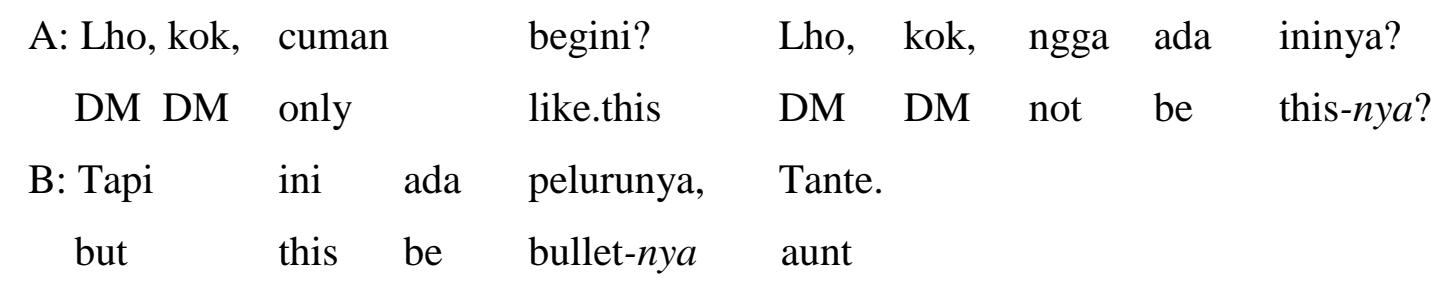

A: How come it is just like this? How come it is missing?

B: But it has the bullet, Aunt.

In another dialogue, the sequences of lho kok was produced by both speakers. A repeated lho kok two times in his first utterance. Then, A and B produced one question with lho kok. From the utterance lho kok, the speakers said that that it should not be like this.
A: Lho...
Lho kok ada
tiga? Lho, kok ada
empat?
$\mathrm{DM}$
DM DM be
three DM
DM be
four
B. Lho, kok banyak?
DM DM many 


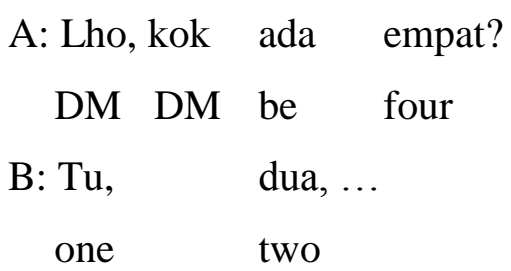

A: How come there are three things? How come there are four things?

B: How come there are many?

A: How come there are four?

B: One, two, ... .

None of the speakers answered the dialogue. They only questioned. It seems that the questioning sense is stronger in this dialogue.

In the other dialogue, lho kok occurs with wah which is an interjection. It forms wah lho kok. After asking for the reason, speaker A asked the person that did it. Then, he questioned the reason again. In this question, he did not produce wah and loh. Kok occurs without any markers because the speaker was not as shocked as when he produced the first question. In the first utterance, he produced three questions. The first and the last questions talk about the same issue.

$\begin{array}{clllll}\text { A: Wah, } & \text { lho, } & \text { kok } & \text { miring } & \text { ni? } & \\ \text { DM } & \text { DM } & \text { DM } & \text { slanting } & \text { this } & \\ \text { A: Siapa } & \text { sih } & \text { yang } & \text { mutusin, } & \text { kok } & \text { miring? } \\ \text { who } & \text { DM } & \text { which } & \text { break } & \text { DM } & \text { slanting } \\ \text { B: Oh, } & \text { karena } & \text { dimasukin } & \text { ke } & \text { kardus. } \\ \text { DM } & \text { because } & \text { put } & \text { into } & \text { box }\end{array}$

A: Wow. How come it is slanting? Who broke it? How come it was slanting?

B: Oh, because it was put into the box.

Three questions that occur in one speaking turn show that it makes the tone of the dialogue becomes more questioning. The participant observed the object and it led him to produce questions related to the objects.

\section{Eh and Kok}


Co-occurences of $e h$ and $k o k$ can be in a statement or question. In the following example, it occurs in a question. They discussed about the train such as experience and where the train is. Then, B asked questioned. He asked the question which begins with $e h \ldots k o k$. Eh ... kok shows that he just noticed new thing. He made it as the topic that he would discuss and tried to make the others notice. Through his question, speaker A raised new topic about the train. In this question, he used the word tapi (but) which shows contrast. He contrasted what he found about the train that the train does not move with his concept that the train should move.

$\begin{array}{lllllll}\text { A: Kereta api. Ya } & \text { kan } & \text { Om } & \text { Oki. } & & \\ \text { Train } & \text { DM } & \text { DM } & \text { uncle } & \text { O } & & \\ \text { B: Iya, } & \text { bener, kok } & & \text { tau, } & \text { Mamas? Emang } & \text { pernah ...? } \\ \text { yes } & \text { right } & \text { how come } & \text { know } & \text { M } & \text { actually } & \text { ever } \\ \text { C: } \text { Kan ... } & & & & & & \\ \text { DM } & & & & & & \\ \end{array}$

$\begin{array}{cl}\text { A: Pernah } & \text { naik } \\ \text { ever } & \text { take } \\ \text { C: Kalo } & \text { kalo ... } \\ \text { if } & \text { if }\end{array}$

$\begin{array}{ccc}\text { A: Pernah } & \text { liat } & \text { kok } \\ \text { ever } & \text { see } & \text { DM } \\ \text { C: Kalo } & & \\ \text { if } & & \end{array}$
A: Di stasiun
at train.station
B: Eh, tapi kok ngga bisa jalan ya? Exc but DM not can work DM
D: Eeh.

Exc.
A: Train. Is it right, Uncle Oki?
B. Yes, that's right. How come you know it, Mamas? Actually ... ?
C: Yeah ....
A: I took it 
C: If $\ldots$, if $\ldots$.

A: I saw it, you know.

C. If ....

A: At the train station.

B: Anyway, but how come it cannot work?

D: Yeah.

Eh and kok also occurs in a statement. As a statement, the function of kok is to emphasize. Therefore, it makes others notice particular facts that would be said by the speaker. It can be said as speaker's way to emphasize his utterance. A complained about his aunt that did not want to help. As a response to this complain, $\mathrm{C}$ (aunt) made A realized why she did it.

(9) A: Cepet, cepet. Masuk rumah semua! Masuk rumah! Masuk rumah! hurry hurry come house all come house come house

B: Ayo cepet.

come on hurry

A: Wa, tante! Bantuin dong! Aah, tante nih nggak mau bantuin.

Exc aunt help DM DM aunt DM not want help

C: Eh, yang maen kamu kok.

DM which play you DM

A: Hurry, hurry. Come to the house, all. Come to the house. Come to the house.

B: Come on. Hurry.

A: Aunt, please help. Ah, aunt is not willing to help.

$\mathrm{C}$ : Hey, it is you that play.

\section{Oh and Kok}

The co-occurences can be seen in the form of questions and statements. In the example below, the co-occurrence is in the question. $\mathrm{Oh}$ is closed to the information given in discourse.

$\begin{array}{clllll}\text { A: Tante, } & \text { ni } & \text { sosis } & \text { sisanya } & \text { dari } & \text { sekolah. } \\ \text { Aunt } & \text { this } & \text { sausage } & \text { rest-nya } & \text { from } & \text { school }\end{array}$




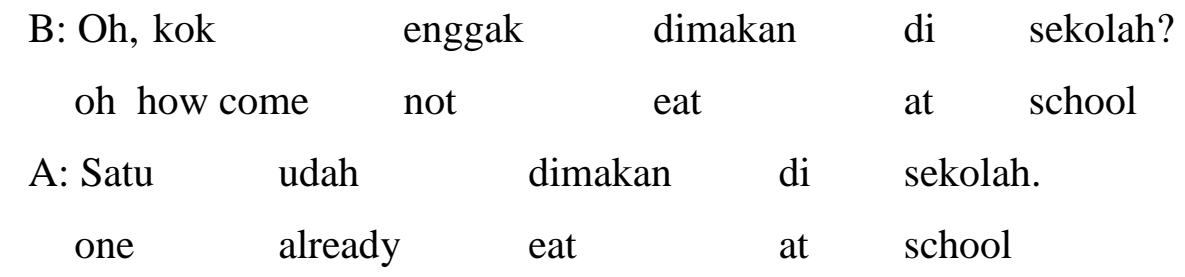

A: Aunt, here is/are (a) leftover sausage(s) from the school.

B: Oh, how come you didn't eat it at the school?

A: I ate it one at the school.

$\mathrm{B}$ gave response to the information given by A. When the speaker used $o h$, she just knew the information because the speaker told her. $O h$ also functions to notice that the speaker paid attention to the interlocutor. It is in line with the functions of oh mentioned by Schirffrin (1993). Based on the information given, B asked a question using kok. A did not directly give the reason. He added another information that can be used by B to guess.

As a statement, oh and kok occurs in the following dialogue. $O h$ is a response to B question. However, the response was not given directly after the question. There is an utterance produced by A before A answered the question. In this dialogue, speaker A did some actions. She was able to answer the question after doing this action. Oh .. kok in the following example shows that the speaker has just known particular fact and emphasize the fact.

$\begin{array}{cllll}\text { A: Tante, } & \text { Bety } & \text { mo pipis dulu ya. } \\ \text { aunt } & \text { B } & \text { want pee early DM } \\ \text { B: Oh iya. } & \text { Bisa nggak pipis sendiri? } \\ \text { oh yes } & \text { can not pee alone } \\ \text { A: Ah, } & \text { ininya dilepas. } & \\ \text { Ex } & \text { this free } & \\ \text { C: Yah. } & & & \\ \text { DM } & & & \end{array}$
A: Oh bisa kok itu. oh can DM that

A: Aunt, Bety wants to pee first.

B: Yes. Can you pee alone?

A: Ah, it should be opened.

C: Oh, no. 
A: Oh, it worked, you know.

\section{Lha and Kok}

A shows his wonder by using lha kok. Instead of giving reason to A, he asked a question too. A asked again but in this question, he did not use lha. This case is similar to the cooccurences of lho and kok. Lha did not appear because it is not the first time for him to know it. In the first question, it was the first time for her to realize the fact. Then, he questioned it with lha kok. In the second question, speaker $\mathrm{C}$ gave explanation as a response.
A: Lha
kok ada kacang?
$\mathrm{DM}$
$\mathrm{DM}$ there peanut
C: Yang satu lagi mana? which one again where
A: Kok ada kacang?
DM there peanut

$\begin{array}{cllll}\text { B: Mana? } & \text { Ya udah } & \text { tambahin kacang } & \text { juga nggak pa pa, } & \text { enak. } \\ \text { which } & \text { okay } & \text { add peanut } & \text { also not.problem } & \text { yummy }\end{array}$
A: What. How come there are peanuts?
$\mathrm{C}$ : Where is the other one?

A: How come there are peanuts?

B: Which one? Okay. It's not a problem to add peanuts. Yummy.

In another dialogue, the speaker produced two questions in one utterance. In the first question, lha occurs with kok. However, in the second question, it occurs without lha. This is still in line with the case in the previous dialogue where the speakers produced two questions with kok. Kok occurs with lha in the first question. However, it appears without any other DM in the second one.

$\begin{array}{ccllll}\text { (13) A: Lha } & \text { kok } & \text { gambar } & \text { semua ni? } & \\ \text { DM } & \text { DM } & \text { picture } & \text { all this } & \\ \text { A: Ni } & \text { kok } & \text { nggak ada } & \text { gambarnya } & \text { kayak ini? } \\ \text { this } & \text { DM } & \text { not be } & \text { picture } & \text { like this } \\ \text { B: Oh, nggak } & \text { ada. } & \text { Ini juga } & \text { nggak ada. } & \end{array}$


oh not there this also not there

A: What. How come all are pictures? How come it doesn't have a picture like this?

B: There aren't any. This one also doesn't have.

B did not give reasons. He only emphasized the point that A mentioned. He also made the last statement to show that the same case also happens.

In the dialogue below, A produced question with kok based on his observation. Then, B gave a response. A asked another question with a different topic. In this question, kok occurs with lha.

$\begin{array}{cll}\text { A: Eh, } & \text { bikin setan aja deh. } \\ \text { Exc } & \text { make devil just DM } \\ \text { B: Bikin } & \text { setan? } \\ \text { make devil } & \\ \text { C: (S)etan di hutan, kalo malem-malem. } \\ \text { devil } & \text { at forest if night } \\ \text { B: Ni } & \text { malem-malem ni ceritanya. } \\ \text { this } & \text { night this story-nya } \\ \text { A: Iya. } & \text { Kok begitu } & \text { sih? } \\ \text { yes } & \text { DM like.that } & \text { DM } \\ \text { B: Nanti } & \text { dulu, belom jadi. } \\ \text { later } & \text { before not.yet become }\end{array}$

$\begin{array}{clll}\text { A: Lha kok, } & \text { eee, } & \text { setannya } & \text { terbang? } \\ \text { DM } & \text { DM } & \text { exc } & \text { devil-nya fly }\end{array}$

B: Terbang.

Fly
A: Hey. Let's just make devil.
B: Make devil?
C: Devil is at the forest at night.
B: Let's say it is night.

A: How come it is like this.

B: Later. It hasn't been finished.

A: How come devil flies.

B: Fly. 
The case here is different from the case previously discussed. In this case, kok without DM occurs first. It happens differently because in this case, the speaker asked for two different things.

\section{Wah and Kok}

Kok that occurs with wah gives sense of wonder. Wah ... kok is an expression of wonder of what $\mathrm{C}$ saw. It triggered his curiosity that led him to produce a question with kok. There is no response towards C's question. A switched the topic. Then, C gave a response to a new topic.
(15) A: Ni Mamas
bikin anjing.
this Mamas
make dog
B: Tuh.
that
C: He em.

\section{$\mathrm{DM}$}
A: Setan
devil
C: Wah, setannya kok kayak cacing?
Exc devil-nya DM like worm
A: Ini rumputnya.
this grass-nya
C: Apa tuh, rumput, Mas? what that grass $\mathbf{M}$
A: Now, Mamas is making a dog.
B: That one.
C: Yes.
A: Devil
$\mathrm{C}$ : Wow. How come the devil is like a worm? 
A: This is the grass.

B: What is it? Is it grass, Mas?

In another dialog, there are two questions in a speaking turn. It is only the second question that used kok. Even though the first question did not use kok (ini mana ini?), the sense of questioning is still strong in the utterance that creates the nuance of questioning in the dialogue.

$\begin{array}{cllll}\text { A: Ini } & \text { mana ini? } & \text { Wah, ini kok } & \text { copot? } \\ \text { this } & \text { which this } & \text { DM this how.come } & \text { detached } \\ \text { B: Harus } & \text { dua tapi, } & \text { nggak boleh. } & \\ \text { must } & \text { two but not can } & \end{array}$

A: Where is it? Wow, how come it is detached?

B: But, it must be two. It can't be.

In this case, there is no reason given to answer A's question.

\section{Ih and Kok}

When ih occurs with $k o k$, there is a sense of questioning with negative feeling that makes the speaker felt horrific. In the following dialogue, the negative feeling is dirty because the hair should not be there.

$\begin{array}{clll}\text { (17) } \text { Tuh } & \text { ada tissue. } \\ \text { that } & \text { there tissue } & \\ \text { B: Heh? } & & \\ \text { What } & & & \\ \text { A: Pake } & \text { tissue, } & \text { ya? } & \\ \text { use } & \text { tissue } & \text { DM } & \\ \text { C: } \text { Ih, } & \text { kok } & \text { ada rambut sih? } \\ \text { Exc } & \text { how.come be hair DM }\end{array}$

A: That is a tissue.

B: Eh?

A: Use a tissue, don't you?

C: How come the hair is there?

In the other case, the negative feeling is shame. A did self-talking in which he asked a question and express what he felt. The other speakers did not give a response. B talked about new topic. Then, $\mathrm{C}$ responded to this new topic. 

A: Ih,
ce(lana),
celananya
kok
gitu?
$\mathrm{DM}$
pants-nya
pants-nya
how.come
like.that?
A: Ih,
malu.
Om Okki malu.
DM
ashamed
Uncle $\mathrm{O}$
ashamed.

B: Diminum, Mas Okki.

drink Mas Okki

C. Iya, Bu.

yes ma'am

A: Yuck. The pants. How come the pants like that? Yuck. Uncle Okki, I am ashamed.

B: Have a drink, Mas Okki.

C: Yes, Ma'am.

\section{Sih and Kok}

Sih is the only DM that occurs on the right side of $k o k$. In the questions, sih plays a role to make the dialogue smooth and emphasize the focus of questions (Sneddon, 2006). Kok can occur in the beginning of the sentence after the addressing term. In the following example, kok occur after the addressing term, ma. Ma means mama (mother).
A: Ma, kok nggak ada
kulitnya sih?
Ma how.come not be skin-nya
$\mathrm{DM}$
B: Kulitnya susah dong. skin-nya hard DM

A: Ma, how come it doesn't have a skin.

B: The skin is hard.

In the dialogue above, A asked her mother, a person that must be respected based on local culture. Based on participants' relationship, A tried to smooth the question by using sih. The question used kok which demand an explanation. To make it less demanding, the speaker used sih.

In another case, kok occurs in the middle of the sentence. B responded by mentioning the issue that was mentioned by speaker A before he gave the reason.
A: Si Atan kok
nggak keliatan
$\operatorname{sih}$ ? 


$\begin{array}{cllll}\operatorname{dim} \text { Atan } & \text { how.come } & \text { not } & \text { seen } & \text { DM } \\ \text { B: Nggak } & \text { keliatan, } & \text { Atan di } & \text { bawah. } \\ \text { not } & \text { see } & \text { Atan } & \text { at } & \text { under }\end{array}$

A: How come I didn't see Atan?

B: I didn't see him. Atan is on the ground below.

The co-occurrences of $s i h$ and kok in the two dialogues above emphasize the focus of the questions to the listeners. By doing so, the speakers directed the listener to get the focus of the questions. Thus, the listeners would give more relevant information to answer the questions. It is in line with what was mentioned by Han (2011) that DMs are intended by the speakers to the make the listeners interpret the messages correctly.

\section{CONCLUSION}

In terms of emotive functions, the co-oocurences carry the expressions of shock and surprise. It is also possible that expressions of disappointment and horrific gives nuance to the dialogue. The speakers concern towards particular issues and have curiousity about the issues. It led them to the make questions with the co-ccurences of kok and other markers. Two questions with kok might be produced in one utterance. One of them might carry cooccurences of kok and other markers whereas the other one has only kok. In terms of textual functions, the co-occurences play roles to address new topics, show information that is taken and given, make the other participants notice about particular issues, and smooth the dialogues.

\section{REFERENCES}

Aijmer, K. \& Rühlemann, C. (2014). Corpus pragmatics: Laying the foundations. In K. Aijmer \& C. Rühlemann, In Corpus pragmatics: A handbook. Cambridge: Cambridge University Press.

Anthony, L. (2014). AntConc (Version 3.4.3) [Computer Software]. Tokyo, Japan: Waseda University. Downloaded from http://www.laurenceanthony.net/

Blakemore, D. (2004). Discourse markers. In L. Horn \& G. Ward (Eds.), In The handbooks of pragmatics (pp. 221-240) Malden: Blackwell Publishing.

Biber, D., Johansson, S., Conrad, S. \& Finegan, E. (1999). Longman grammar of spoken and written English. London: Longman.

Child Language Data Exchange System. (n.d.). Retrieved from http: http://childes.talkbank.org/browser/index.php?url=EastAsian/Indonesian/Jakarta/

Fischer, K. (n.d.). Discourse markers, turn-taking, and the semantics-pragmatics interface. https://nats-www.informatik.uni-hamburg.de/ fischer/rspfischer.pdf

Fraser, B. (1996). Pragmatic markers. Pragmatics, 6 (2), 167-190. 
Furman, R. \& Özyürek, A. (2007). Development of interactional discourse markers: Insights from Turkish children's and adults' oral narratives. Journal of Pragmatics, 39 (10), 1742-1757. doi:10.1016/j.pragma.2007.01.008

Han, D. (2011). Utterance production and interpretation: A discourse-pragmatic study on

pragmatic markers in English public speeches. Journal of Pragmatics, 43, 2776-2794. doi:10.1016/j.pragma.2011.04.008

Hiramoto, M. (2012). Pragmatics of the sentence-final uses of can in colloquial Singapore English. Journal of Pragmatics 44, 890-906. doi: 10.1016/j.pragma.2012.03.013

Kamus Besar Bahasa Indonesia. (2016). Retrieved from https://kbbi.web.id/

Mutiara, R. (2017). Particle kok in child language: Stance and positions. In Yanti (Ed.), Celebrating corpus tools. Proceedings of the the 4th Atma Jaya Conference on Corpus Studies (pp. 11-15). Jakarta, Indonesia.

Neal, N. (2014). Interjections. In K. Aijmer \& C. Rühlemann, In Corpus pragmatics: A handbook. Cambridge: Cambridge University Press.

Rühlemnann, C. (2010). What can a corpus tell us about pragmatics?. In A. O'Keeffe \& M. McCarthy, In The Routledge Handbook of Corpus Linguistics. New York: Routledge.

Schiffrin, D. (1987). Discourse markers. Cambridge: Cambridge University Press.

Schiffrin, D. (1992). Discourse markers. Cambridge: Cambridge University Press.

Schiffrin, D. (2003). Discourse markers: Language, meaning, and context. In D. Tannen, D. Schiffrin, \& H. E. Hamilton, In The handbook of discourse analysis. Oxford: Blackwell Publishing.

Sneddon, J. (2006). Colloquial Jakartan Indonesian. Australia: The Australian National University.

Thornbury, S. (2010). What can a corpus tell us about discourse?. In A. O'Keeffe \& M. McCarthy, In The Routledge Handbook of Corpus Linguistics. New York: Routledge.

Wang, Y. (2011). A discourse-pragmatic functional study of the discourse markers Japanese ano and Chinese nage. Intercultural Communication Studies XX, 41-61. 